\title{
Article \\ UV-Responsive Screen-Printed Porous ZnO Nanostructures on Office Paper for Sustainable and Foldable Electronics
}

\author{
Sofia Henriques Ferreira (D), Inês Cunha, Joana Vaz Pinto, Joana Pereira Neto (D), Luís Pereira, Elvira Fortunato * \\ and Rodrigo Martins *(D)
}

check for

updates

Citation: Ferreira, S.H.; Cunha, I.;

Pinto, J.V.; Neto, J.P.; Pereira, L.;

Fortunato, E.; Martins, R.

UV-Responsive Screen-Printed

Porous ZnO Nanostructures on Office Paper for Sustainable and Foldable

Electronics. Chemosensors 2021, 9, 192.

https://doi.org/10.3390/

chemosensors 9080192

Academic Editor: Núria Serrano

Received: 30 June 2021

Accepted: 20 July 2021

Published: 24 July 2021

Publisher's Note: MDPI stays neutral with regard to jurisdictional claims in published maps and institutional affiliations.

Copyright: (c) 2021 by the authors. Licensee MDPI, Basel, Switzerland. This article is an open access article distributed under the terms and conditions of the Creative Commons Attribution (CC BY) license (https:// creativecommons.org/licenses/by/ $4.0 /)$.
i3N/CENIMAT, Department of Materials Science, Faculty of Science and Technology, Campus de Caparica, Universidade NOVA de Lisboa and CEMOP/UNINOVA, 2829-516 Caparica, Portugal; sdl.ferreira@campus.fct.unl.pt (S.H.F.); i.cunha@campus.fct.unl.pt (I.C.); jdvp@fct.unl.pt (J.V.P.); joana.neto@campus.fct.unl.pt (J.P.N.); lmnp@fct.unl.pt (L.P.)

* Correspondence: emf@fct.unl.pt (E.F.); rm@uninova.pt (R.M.); Tel.: +351-212948562 (E.F. \& R.M.)

\begin{abstract}
The fabrication of low-cost, flexible, and recyclable electronic devices has been the focus of many research groups, particularly for integration in wearable technology and the Internet of Things (IoT). In this work, porous zinc oxide $(\mathrm{ZnO})$ nanostructures are incorporated as a UV sensing material into the composition of a sustainable water-based screen-printable ink composed of carboxymethyl cellulose (CMC). The formulated ink is used to fabricate flexible and foldable UV sensors on ubiquitous office paper. The screen-printed $\mathrm{CMC} / \mathrm{ZnO} \mathrm{UV}$ sensors operate under low voltage $(\leq 2 \mathrm{~V})$ and reveal a stable response over several on/off cycles of UV light exposure. The devices reach a response current of $1.34 \pm 0.15 \mathrm{~mA}$ and a rise and fall time of $8.2 \pm 1.0$ and $22.0 \pm 2.3 \mathrm{~s}$, respectively. The responsivity of the sensor is $432 \pm 48 \mathrm{~mA} \mathrm{~W}^{-1}$, which is the highest value reported in the literature for ZnO-based UV sensors on paper substrates. The UV-responsive devices display impressive mechanical endurance under folding, showing a decrease in responsivity of only $21 \%$ after being folded 1000 times. Their low-voltage operation and extreme folding stability indicate a bright future for low-cost and sustainable flexible electronics, showing potential for low-power wearable applications and smart packaging.
\end{abstract}

Keywords: $\mathrm{ZnO}$ nanostructures; porous $\mathrm{ZnO}$; paper substrates; microwave synthesis; UV sensing; sustainable electronics; foldable electronics

\section{Introduction}

Paper is a renewable raw material that has been used by humankind for thousands of years to share and store information. Over the last few decades, many researchers and industries have not been looking at paper for its conventional application of transmitting information, but as a substrate for the development of low-cost, flexible, and recyclable electronic devices that will in a close future find their place in our daily life, thus leading to a revolutionary and sustainable era of electronics [1-5].

Cellulose, known as the most abundant and renewable biopolymer on Earth, is the building block of paper, and therefore responsible for its beneficial features, such as lightweight, low thermal expansion, flexibility/foldability, biodegradability, and recyclability [5]. Paper is also compatible with roll-to-roll (R2R) manufacturing processes, and it is available in several textures, compositions, and coatings [4,6,7].

The idea of using ubiquitous paper substrates as a low-cost, flexible, and robust support for printed electronic applications has already been demonstrated on memory devices [8], chromogenic displays [9-11], photovoltaics cells [12], paper-based microfluidic devices [13], and transistors and integrated circuits [14-21]. Inspired by the pioneer work introduced in our research group by Fortunato et al. [22] in 2008, Grey et al. [21] also successfully explored the intrinsic dielectric/electrolytic properties of paper, which was 
used not only as a substrate but also as an active electronic material to work as the gate dielectric layer in printed/handwritten $\mathrm{ZnO}$ transistors.

Paper electronics relies on the development of stable, low-cost, non-toxic, and environmentally friendly printable inks to deposit and pattern functional materials onto paper [23]. Printable inks consist of a combination of functional materials, binders, additives, and solvents, each one impacting the inks' viscosity, rheology, evaporation rate, and surface tension $[23,24]$. There is an increasing interest in the development of water-based inks, since water is a cheap and eco-friendly solvent [25]. Cellulose derivatives, such as carboxymethyl cellulose (CMC), have been applied as a biopolymeric binder in the formulation of water-based printable inks [26-28].

However, the large surface roughness, high absorption capacity, and porosity in conventional paper speed up lateral spreading of the inks, leading to low-resolution and irregular/deformed printed features, thus compromising their functionality $[16,29,30]$. These adverse effects can be overcome with the use of inks with a "honey-like" viscosity (0.03-50 Pa s), such as the ones compatible with the screen-printing technique, since they enable the deposition of thicker films while preventing the excessive bleeding and swelling of the cellulose fibers [31]. This printing technique is widely used in printed electronics due to its simple operation, ease of prototyping, no need of complex equipment, fast printing speed $\left(150 \mathrm{~m} \mathrm{~min}^{-1}\right)$, compatibility with substrates with tailored textures, and versatility of pattern designs (resolution around 30-100 $\mu \mathrm{m}$ ) [32-34].

From a broad list of functional materials, $\mathrm{ZnO}$ is an n-type semiconductor with a wide bandgap of $3.37 \mathrm{eV}$ and high exciton binding energy of $60 \mathrm{meV}$ at room temperature that crystalizes in a hexagonal wurtzite structure [35]. The simple synthesis methods that exist to produce $\mathrm{ZnO}$ nanostructures with tailored sizes and morphologies, along with low-temperature processability $\left(<300^{\circ} \mathrm{C}\right)$, chemical and thermal stability, abundant availability, and non-toxic nature, among several other features, makes $\mathrm{ZnO}$ one of the most investigated metal semiconductor oxides in a wide range of applications [36-45]. Among all the existing synthesis methods to obtain $\mathrm{ZnO}$ nanostructures, microwave hydrothermal/solvothermal synthesis is particularly interesting due to the high reaction rates that result from the absorption of microwave radiation by the materials. As a result, a homogeneous and fast volumetric heating is obtained during synthesis, which allows the production of $\mathrm{ZnO}$ nanostructures in minutes [46-52].

$\mathrm{ZnO}$ nanostructures have been employed before in the development of screen-printable inks for paper electronic applications. In our group, several works have been published reporting the fabrication of screen-printable inks based on cellulose derivatives and commercial $\mathrm{ZnO}$ nanoparticles for a variety of applications, such as UV sensors [53,54], field effect transistors [21], and electrolyte-gated transistors [20]. Besides paper electronics, ZnO-based pastes and inks have also been developed for a wide range of applications, including solar cells [55], photoelectrochemical cells [56], gas sensors [57], and light-emitting diodes [58].

$\mathrm{ZnO}$ nanostructures with a porous morphology are advantageous for sensing applications, as a high number of pores result in high specific surface areas for the adsorption of molecules, thus enhancing their sensing responsivity [59,60]. Although there are several reports that demonstrate the superior performance of porous $\mathrm{ZnO}$ nanostructures in gas sensors [60-64], dye-sensitized solar cells [65], batteries [66], photocatalysis [67-69], and biosensing [70], their performance in paper-based UV sensors has not yet been exploited.

Porous $\mathrm{ZnO}$ nanostructures can be produced by calcination of layered zinc hydroxide (LZH) materials [68], particularly LZHs intercalated by carbonate ions (LZHC) [66,68,71-73]. LZHC nanomaterials can be obtained by hydrothermal synthesis with a plate-like morphology assembled in 3D hierarchical structures and then be converted into porous $\mathrm{ZnO}$ nanostructures by calcination at high temperatures while maintaining a similar morphology, as demonstrated in our previous works $[67,74]$.

Within this context, this work reports the fabrication of porous $\mathrm{ZnO}$ nanostructures with a plate-like morphology by microwave hydrothermal synthesis of LZHC and its sub- 
sequent calcination at $700{ }^{\circ} \mathrm{C}$. The synthesized porous $\mathrm{ZnO}$ nanostructures were employed in the formulation of a water-based screen-printable $\mathrm{CMC} / \mathrm{ZnO}$ composite ink. To the best of our knowledge, this is the first work reporting the incorporation of $\mathrm{ZnO}$ nanostructures with a porous morphology in a water-based screen-printable ink. The fabricated ink was integrated into UV sensors built onto office paper. The photonic devices were tested under different applied voltages and UV light intensities, and their mechanical endurance was also investigated. Their UV responsiveness far exceeds the ones reported in the literature when using $\mathrm{ZnO}$ nanostructures together with cellulosic materials/substrates, reaching response currents in the $\mathrm{mA}$ range when operating under low voltage $(2 \mathrm{~V})$.

\section{Materials and Methods}

\subsection{Synthesis and Characterization of Porous $\mathrm{ZnO}$ Nanostructures}

Following the procedure reported in our previous work [67], porous $\mathrm{ZnO}$ nanostructures were synthesized by hydrothermal method assisted by microwave irradiation. Briefly, $0.05 \mathrm{M}$ of zinc nitrate hexahydrate $\left(\mathrm{Zn}\left(\mathrm{NO}_{3}\right)_{2} \cdot 6 \mathrm{H}_{2} \mathrm{O}, 98 \%\right.$ from Sigma-Aldrich, St. Louis, MO, USA) was first dissolved in deionized water, followed by the addition of urea $\left(\mathrm{CH}_{4} \mathrm{~N}_{2} \mathrm{O}, 99.0-100.5 \%\right.$ from Sigma-Aldrich, St. Louis, MO, USA) to the aqueous solution in a molar ratio of zinc to urea of 1:5. The synthesis was carried out in a Discovery SP microwave (CEM, Matthews, NC, USA) at $140{ }^{\circ} \mathrm{C}$ for $15 \mathrm{~min}$ under a power of $100 \mathrm{~W}$. After the synthesis, the resulting white precipitates were washed with deionized water followed by isopropanol and centrifuged at $4000 \mathrm{rpm}$ for $5 \mathrm{~min}$ each. This washing process was repeated three times. The powders were dried in air at room temperature and then calcinated in a muffle furnace (Nabertherm $\mathrm{GmbH}$, Lilienthal, Germany) at $700{ }^{\circ} \mathrm{C}$ for $2 \mathrm{~h}$ in air at a heating rate of $250{ }^{\circ} \mathrm{C} \mathrm{h}^{-1}$.

The morphology of the $\mathrm{ZnO}$ nanostructures was evaluated via scanning electron microscopy (SEM) using a Carl Zeiss AURIGA CrossBeam FIB-SEM workstation with an Oxford X-ray energy dispersive spectrometer (Carl Zeiss Microscopy GmbH, Oberkochen, Germany). The powder was spread on aluminum stubs using a double-sided carbon tape and coated with a thin iridium layer $(<20 \mathrm{~nm})$ using a Q300T D Quorum sputter coater (Quorum Technologies, East Sussex, UK).

\subsection{Formulation of the $\mathrm{CMC} / \mathrm{ZnO}$ Composite Ink}

The produced porous $\mathrm{ZnO}$ nanostructures were blended with a concentration of $10 \mathrm{wt} \%$ into a previously prepared solution of $3 \mathrm{wt} \%$ of CMC (Mw $\approx 250,000$, SigmaAldrich, St. Louis, MO, USA) dissolved in deionized water. The mixture was slowly stirred at $200 \mathrm{rpm}$ for $4 \mathrm{~h}$ to obtain a well dispersed and homogeneous white viscous solution. The ink was stored in a refrigerator at $3^{\circ} \mathrm{C}$ until being used.

\subsection{Fabrication and Characterization of the CMC/ZnO UV Sensors on Office Paper}

As illustrated in Figure 1, carbon electrodes were screen-printed on office paper $\left(80 \mathrm{~g} \mathrm{~m}^{-2}\right.$, The Navigator Company, Portugal) using a conductive carbon paste (CRSN2644 C INK, Sun Chemical, USA), and a screen mold made of polyester with the following conditions: mesh model, 120-34; mesh count, 305 mesh/inch; aperture, $45 \mu \mathrm{m}$; thread diameter, $34 \mu \mathrm{m}$; opening, 30.5\%; fabric thickness, 52-57 $\mu \mathrm{m}$. The planar electrodes were screen-printed with an interdigital architecture composed of seven pairs of interdigital fingers with a width of $200 \mu \mathrm{m}$ and length of $7.5 \mathrm{~mm}$ spaced from each other with a gap of $200 \mu \mathrm{m}$. The carbon electrodes were dried at $100{ }^{\circ} \mathrm{C}$ for $15 \mathrm{~min}$ in air.

The formulated $\mathrm{CMC} / \mathrm{ZnO}$ ink was then screen-printed in a square shape $\left(6 \times 6 \mathrm{~mm}^{2}\right)$ between the planar carbon electrodes with a different polyester screen (mesh model, 77-55; mesh count, 190 mesh/inch; aperture, $81 \mu \mathrm{m}$; thread diameter, $55 \mu \mathrm{m}$; opening, 30\%; thickness, 88-97 $\mu \mathrm{m}$ ) and dried at room temperature. Morphological characterization of the screen-printed CMC/ZnO layers was performed via SEM. 
(a)
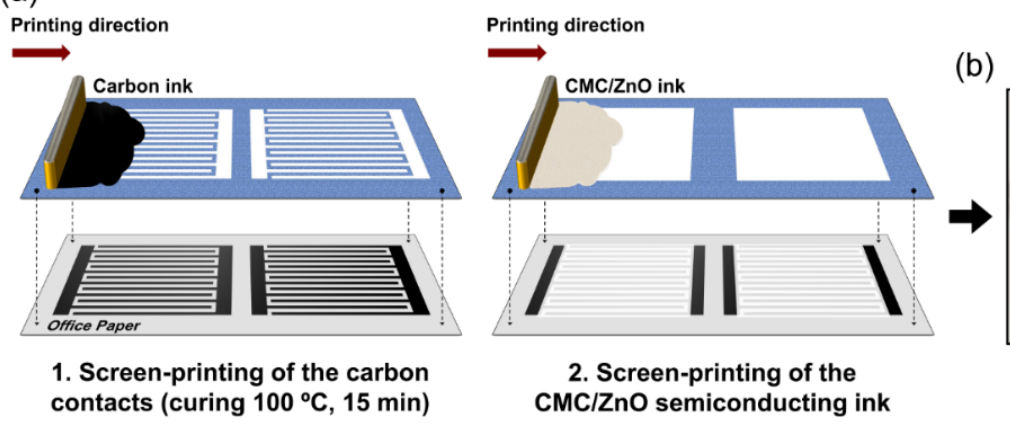

(b)

$\mathrm{CMC} / \mathrm{ZnO}$ semiconducting ink

Figure 1. (a) Schematic of the fabrication process of the screen-printed CMC/ZnO UV sensor on office paper. (b) Optical image of a single screen-printed UV sensor on office paper.

\subsection{Electrical Characterization of the Screen-Printed UV Sensors on Office Paper}

The sensor devices were electrically analyzed in air at room temperature using a microprobe station (Everbeing Int'l Corp., Taiwan) connected to a semiconductor parameter analyzer (Agilent 4155C, Keysight Technologies, Santa Rosa, CA, USA).

Chronoamperometry measurements were carried out with a constant applied bias voltage of $2 \mathrm{~V}$. The screen-printed devices were irradiated with UV light at $365 \mathrm{~nm}$ using a fiber-coupled UV LED (4.1 mW, M365F1, Thorlabs Inc., Newton, NJ, USA) controlled by a DC4100 Controller from Thorlabs (Thorlabs Inc., New Jersey, USA) with a pulse train generator (Pulse Pal, Sanworks LLC, Rochester, NY, USA) programmed to turn on and off the UV LED at different intervals of time. The sensors were placed $2 \mathrm{~cm}$ from the light source and they were tested under a UV intensity of $8.66 \mathrm{~mW} \mathrm{~cm}{ }^{-2}$. The sensors were exposed to $60 \mathrm{~s}$ of UV light followed by $90 \mathrm{~s}$ in the dark during several on/off cycles. The UV sensors were also tested under different applied bias voltages $(0.25,0.5,1$, and $2 \mathrm{~V})$, and different UV light intensities $\left(0.30,0.91,2.02,4.27\right.$, and $\left.8.66 \mathrm{~mW} \mathrm{~cm}^{-2}\right)$. The UV light intensity was measured by a Suss MicroTec UV-Optometer (SÜSS MICROTEC SE, Garching, Germany).

To test the mechanical stability, a sensor was manually folded several times $(100,200$, 500, and 1000 times) and flattened again before measuring its photoresponse to UV light under an applied voltage of $1 \mathrm{~V}$ and $\mathrm{UV}$ light intensity of $8.66 \mathrm{~mW} \mathrm{~cm}^{-2}$.

\section{Results and Discussion}

\subsection{Characterization of Porous $\mathrm{ZnO}$ Nanostructures and $\mathrm{CMC} / \mathrm{ZnO}$ Screen-Printed Films}

As reported in our previous work [67], porous $\mathrm{ZnO}$ nanostructures were synthesized through a facile and fast hydrothermal method assisted by microwave irradiation, followed by a washing step to remove remnants of reagents from the synthesis and a calcination step in a furnace to thermally convert the resulting LZHC precursor into $\mathrm{ZnO}$. As demonstrated in that work [67], a calcination process at $700{ }^{\circ} \mathrm{C}$ yields porous $\mathrm{ZnO}$ nanostructures with high crystallinity and larger pore size when compared to lower calcination temperatures, while ensuring a complete conversion of LZHC into ZnO. Therefore, this calcination temperature was selected to prepare the $\mathrm{ZnO}$ nanostructures in this work.

Figure 2a shows the SEM images of the produced $\mathrm{ZnO}$ powders for different magnifications. The porous $\mathrm{ZnO}$ nanostructures consist of many serrate-like porous nanoplates, which are tightly arranged into flower-like 3D hierarchical microstructures. The porous nanoplates are thin ( $<100 \mathrm{~nm}$ thickness), elongated (maximum length: $<3.5 \mu \mathrm{m})$, and exhibit a highly porous surface with a pore size in the range of tens of nanometers which is formed during the calcination step. 
(a)

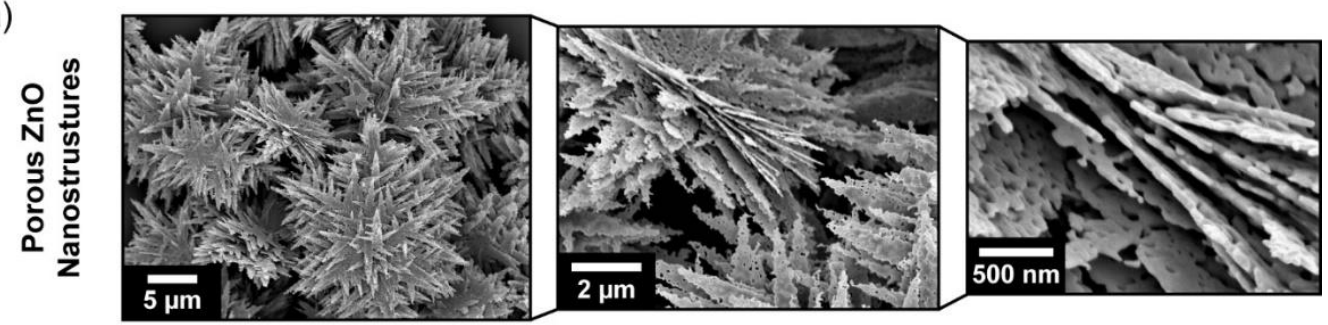

(b)

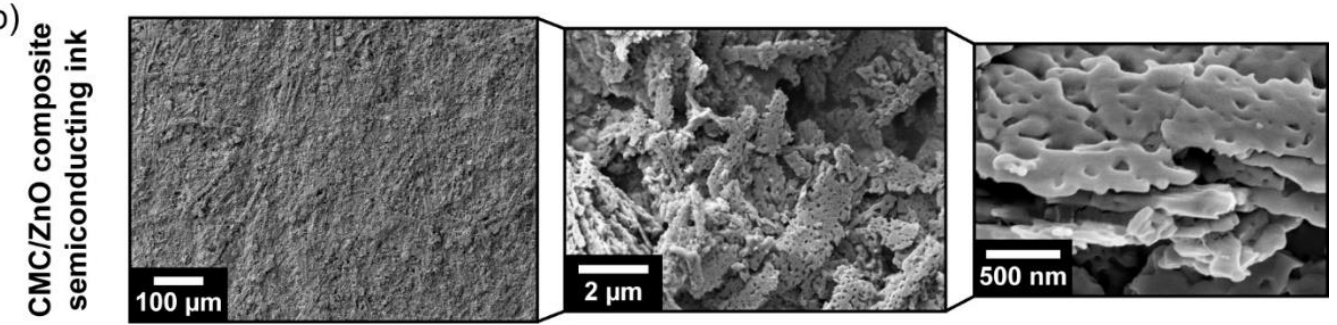

Figure 2. SEM images of (a) the porous $\mathrm{ZnO}$ structures assembled into 3D flower-like hierarchical structures obtained by hydrothermal method assisted by microwave irradiation, and (b) the screenprinted $\mathrm{CMC}$ / porous $\mathrm{ZnO}$ nanostructures composite ink on office paper.

On the other hand, the flower-like morphology is no longer visible on the screenprinted $\mathrm{CMC} / \mathrm{ZnO}$ films (Figure $2 \mathrm{~b}$ ). The mechanical stress induced during the preparation of the inks and the screen-printing process promotes the disassembling of the 2D nanostructures, thus destroying their arrangement in the form of flowers. Despite all the challenges related to office paper surface roughness and absorption, a continuous $\mathrm{CMC} / \mathrm{ZnO}$ composite film with good adhesion to the hydrogen-bonded cellulose fiber network is formed with a single screen-printing step at room temperature, showing no signs of cracks nor peeling. Higher magnifications of the screen-printed films reveal a dense and compact network of stacked and randomly oriented porous $\mathrm{ZnO}$ nanoplates. The elongated size of the porous $\mathrm{ZnO}$ nanostructures promotes a percolation network at low particle loading (10 $\mathrm{wt} \%)$, thus reducing the amount of functional material needed to fabricate the semiconducting ink. Still, some micro-sized voids and agglomerates are visible, which contribute to their rough surface.

\subsection{Characterization of Porous ZnO Nanostructures as UV Sensors}

As depicted in Figure 3a, the UV sensing mechanism is based on the adsorption and desorption of oxygen-rich molecules on the surface of $\mathrm{ZnO}$, and has been previously explained in several works $[48,54,75,76]$. In the dark, oxygen-rich molecules adsorb on the porous $\mathrm{ZnO}$ nanostructures due to the oxygen vacancies that exist in the $\mathrm{ZnO}$ surface, which are known to influence $\mathrm{ZnO}$ electrical conductivity [77]. By adsorbing on the surface of $\mathrm{ZnO}$, the oxygen-rich molecules capture an electron from the conduction band, creating a depletion region on the nanostructures' surface that results in an increase of the electrical resistance of the device. Electron-hole pairs are created when the $\mathrm{ZnO}$ layer is exposed to UV light with energy higher than the $\mathrm{ZnO}$ bandgap. The photogenerated holes migrate to the nanostructures' surface, recombining with the previously captured electrons and, therefore, releasing the adsorbed oxygen molecules from the surface. The generated electrons from the absorption of UV light are now unpaired and available for conduction, leading to a decrease of the depletion region and a subsequent increase of the photocurrent in the UV sensor. 

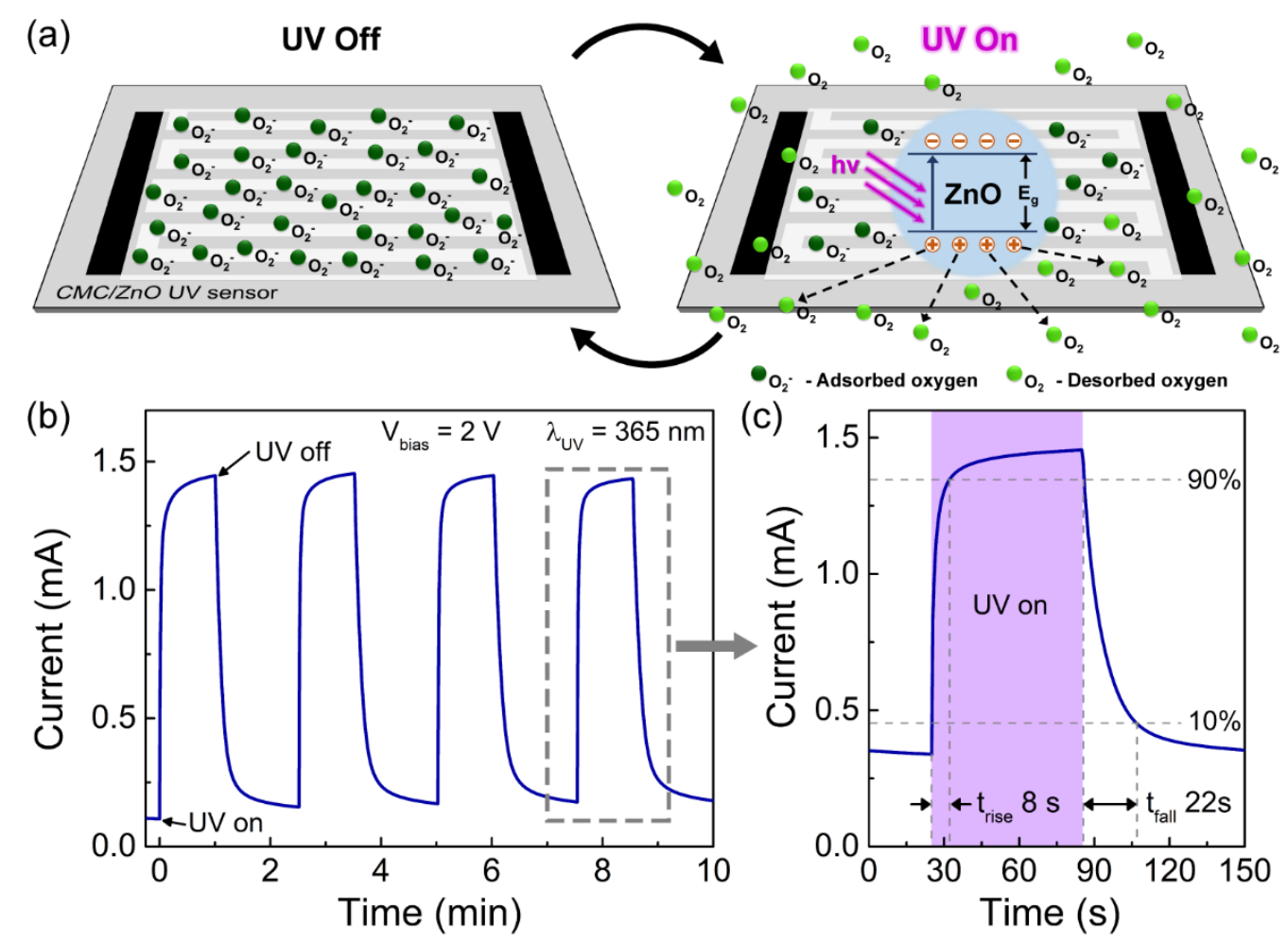

Figure 3. (a) Schematic of the UV sensing mechanism of the screen-printed CMC/ZnO UV sensor on office paper. (b) Average photoresponse of the UV sensor during several on/off UV cycles under a bias voltage of $2 \mathrm{~V}$ for a UV wavelength of $365 \mathrm{~nm}$ and an intensity of $8.66 \mathrm{~mW} \mathrm{~cm}^{-2}$. (c) Magnification of one on/off UV cycle indicating the respective rise $\left(t_{\text {rise }}\right)$ and fall $\left(t_{\text {fall }}\right)$ times.

Figure $3 \mathrm{~b}$ shows the photoelectrical response of the fabricated UV sensors over time for several UV on/off cycles under a bias voltage of $2 \mathrm{~V}$. The photoresponse curve in this figure corresponds to the average response of three tested sensors. The tested sensors were exposed to UV light at $365 \mathrm{~nm}$ with a light intensity of $8.66 \mathrm{~mW} \mathrm{~cm}{ }^{-2}$ for $60 \mathrm{~s}$ followed by $90 \mathrm{~s}$ in the dark. The sensors show a stable photoresponse after successive on/off UV cycles, reaching a maximum average photocurrent $\left(I_{p h}\right)$ of $1.45 \pm 0.23 \mathrm{~mA}$ under UV light and an average dark current $\left(I_{d a r k}\right)$ of $0.11 \pm 0.10 \mathrm{~mA}$. This results in an average response current $\left(\Delta I=I_{p h}-I_{\text {dark }}\right)[78]$ around $1.34 \pm 0.15 \mathrm{~mA}$.

The responsivity $(R)$ of the sensors can be determined by the following expression:

$$
R=\frac{I_{p h}-I_{\text {dark }}}{P_{U V}}
$$

where $P_{U V}$ is the output power of the UV LED ( $3.1 \mathrm{~mW}$ for a UV light intensity of $8.66 \mathrm{~mW} \mathrm{~cm}^{-2}$ and an irradiated area of $36 \mathrm{~mm}^{2}$ ). The average responsivity of the tested sensors was found to be $432 \pm 48 \mathrm{~mA} \mathrm{~W}^{-1}$. As displayed in Figure 3c, the switching response of the UV sensors was also determined to evaluate how fast they respond during (on-state) and after (off-state) exposure to UV light. Therefore, the rise time $\left(t_{\text {rise }}\right)$ was determined by the time required to shift from 10 to $90 \%$ of the maximum photocurrent, while the fall time $\left(t_{\text {fall }}\right)$ corresponds to the time that it takes to decrease from 90 to $10 \%$ when the UV light is turned off $[76,78,79]$. These parameters were determined to be $8.2 \pm 1.0$ and $22.0 \pm 2.3 \mathrm{~s}$ for $t_{\text {rise }}$ and $t_{\text {fall }}$, respectively.

The promising results obtained for the produced $\mathrm{ZnO}$ UV sensors can be attributed to the enhanced adsorption capacity for oxygen-rich molecules on the surface of the porous $\mathrm{ZnO}$ nanostructures due to their large specific surface area as well as the improvement of electron transport properties in $\mathrm{ZnO}$ as a result of both its high crystallinity [67] and plane contacts between the porous nanoplates [63]. Overall, the resistance of the sensing 
layer is strongly affected by the inter-nanostructure barrier at the contacts, meaning that the photoresponse of the sensor is mainly determined by the contacts between the $\mathrm{ZnO}$ nanostructures. In this case, the elongated nanoplate-shape of the porous $\mathrm{ZnO}$ nanostructures results not only in a more direct percolation path for electron transport due to the reduced nanoplates' thickness $(<100 \mathrm{~nm})$ but also in plane-to-plane contacts between the particles. This means that the area of the contact plane is much larger when compared to other nanostructures' morphologies (such as nanowires [80] for example) thus leading to enhanced sensing properties.

Table 1 shows a comparison between our results and the current state-of-the-art values in the field of UV sensors based either on $\mathrm{ZnO}$ nanostructures grown/deposited on paper substrates or $\mathrm{ZnO} /$ cellulose composites. Although these types of $\mathrm{ZnO}$ UV sensors have only been reported since the beginning of the last decade, most of the first published works do not provide a detailed characterization of the sensors. From Table 1, it is clear that the $\mathrm{CMC} / \mathrm{ZnO} \mathrm{UV}$ sensors fabricated in this work show the highest response current and responsivity. For instance, Figueira et al. [54] fabricated screen-printed ZnO UV sensors on cork substrates using an ethyl cellulose/ZnO commercial nanoparticles composite ink. Despite the similar methods involved in the fabrication process, these devices could only reach $20 \mu \mathrm{A}$ under UV light, which is 100 times smaller than the response current obtained in this work. Besides, contrary to our work, a high loading content of small-sized ( $<100 \mathrm{~nm})$ commercial $\mathrm{ZnO}$ nanoparticles $(40 \mathrm{wt} \%$ ) were needed to form a continuous and functional composite matrix on the irregular and punctually defective cork surface. Beyond the listed works displayed in Table 1, the screen-printed CMC/ZnO sensors on office paper also exhibit a comparable or even superior performance than some of recently published ZnO-based UV sensors comprising expensive materials and/or complex, time-consuming and energy-intensive processing methods [75,76,81-85].

Table 1. Comparison of typical measurement parameters ( $V_{\text {bias }}$ and UV light intensity) and respective UV sensor characteristics $\left(t_{\text {rise }}, t_{\text {fall }}, \Delta I\right.$, and $R$ ) obtained for devices based either on $\mathrm{ZnO}$ nanostructures grown/deposited on paper substrates or $\mathrm{ZnO} /$ cellulose composites.

\begin{tabular}{|c|c|c|c|c|c|c|c|}
\hline Materials & 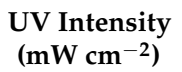 & $\begin{array}{l}\mathrm{V}_{\text {bias }} \\
\text { (V) }\end{array}$ & $\begin{array}{l}t_{\text {rise }} \\
(\mathrm{s})\end{array}$ & $\begin{array}{l}\mathbf{t}_{\text {fall }} \\
(\mathbf{s})\end{array}$ & $\begin{array}{c}\Delta I \\
(\mathrm{~mA})\end{array}$ & $\begin{array}{c}R \\
\left(\mathrm{~mA} W^{-1}\right)\end{array}$ & Reference \\
\hline $\begin{array}{l}\mathrm{CMC} / \mathrm{ZnO} \text { composite on } \\
\text { office paper }\end{array}$ & 8.66 & 2.0 & $8.2 \pm 1.0$ & $22.0 \pm 2.3$ & $1.34 \pm 0.15$ & $432 \pm 48$ & This work \\
\hline $\mathrm{ZnO}$ nanorods on paper & $\mathrm{N} / \mathrm{A}$ & 5.0 & $\mathrm{~N} / \mathrm{A}$ & $\mathrm{N} / \mathrm{A}$ & $5.50 \times 10^{-3}$ & $\mathrm{~N} / \mathrm{A}$ & $\begin{array}{c}\text { Manekkathodi et al. } \\
2010 \text { [86] }\end{array}$ \\
\hline $\mathrm{ZnO}$ powder on paper & $\mathrm{N} / \mathrm{A}$ & 10.0 & $\mathrm{~N} / \mathrm{A}$ & $\mathrm{N} / \mathrm{A}$ & $7.00 \times 10^{-3}$ & $\mathrm{~N} / \mathrm{A}$ & $\begin{array}{l}\text { Gimenez et al. } \\
2011 \text { [87] }\end{array}$ \\
\hline $\mathrm{ZnO}$ nanocrystals on paper & $\mathrm{N} / \mathrm{A}$ & 1.0 & $\mathrm{~N} / \mathrm{A}$ & $\mathrm{N} / \mathrm{A}$ & $9.00 \times 10^{-4}$ & $\mathrm{~N} / \mathrm{A}$ & $\begin{array}{l}\text { Hasan et al. } \\
2012[88]\end{array}$ \\
\hline $\mathrm{ZnO}$ nanoparticles on paper & 1.22 & $\mathrm{~N} / \mathrm{A}$ & 6.0 & 3.0 & $\mathrm{~N} / \mathrm{A}$ & $\mathrm{N} / \mathrm{A}$ & $\begin{array}{c}\text { Kiasari et al. } \\
2014 \text { [89] }\end{array}$ \\
\hline $\begin{array}{c}\mathrm{ZnO}-\text { cellulose } \\
\text { nanocomposite pellets }\end{array}$ & $\mathrm{N} / \mathrm{A}$ & 5.0 & 15.0 & 10.0 & $7.76 \times 10^{-3}$ & $\mathrm{~N} / \mathrm{A}$ & $\begin{array}{l}\text { Sahoo et al. } \\
2017 \text { [90] }\end{array}$ \\
\hline $\begin{array}{l}\text { Direct writing of } \mathrm{ZnO} \\
\text { nanoparticles on paper }\end{array}$ & 3.10 & 1.0 & 33.19 & 18.13 & $2.20 \times 10^{-4}$ & $\mathrm{~N} / \mathrm{A}$ & $\begin{array}{l}\text { Veerla et al. } \\
2017 \text { [91] }\end{array}$ \\
\hline $\begin{array}{c}\text { Commercial } \mathrm{ZnO} \\
\text { nanoparticles on paper }\end{array}$ & $\mathrm{N} / \mathrm{A}$ & 5.0 & 14.7 & 7.5 & $\mathrm{~N} / \mathrm{A}$ & $\mathrm{N} / \mathrm{A}$ & $\begin{array}{l}\text { Grey et al. } \\
2017[21]\end{array}$ \\
\hline $\begin{array}{l}\mathrm{ZnO} \text { nanorods grown on } \\
\text { Whatman paper }\end{array}$ & $\mathrm{N} / \mathrm{A}$ & 10.0 & 57.0 & 65.0 & $9.60 \times 10^{-3}$ & $1.19 \times 10^{-3}$ & $\begin{array}{l}\text { Pimentel et al. } \\
2017 \text { [49] }\end{array}$ \\
\hline $\begin{array}{l}\mathrm{ZnO} \text { nanorods grown on } \\
\text { cellulose film }\end{array}$ & 2.60 & $\mathrm{~N} / \mathrm{A}$ & $<1$ & $\mathrm{~N} / \mathrm{A}$ & $1.34 \times 10^{-3}$ & $\mathrm{~N} / \mathrm{A}$ & $\begin{array}{l}\text { Mun et al. } \\
2017 \text { [92] }\end{array}$ \\
\hline $\begin{array}{l}\mathrm{ZnO} \text { nanorods grown on } \\
\text { Whatman paper }\end{array}$ & $\mathrm{N} / \mathrm{A}$ & 10.0 & $\mathrm{~N} / \mathrm{A}$ & 109.0 & $4.90 \times 10^{-3}$ & $0.61 \times 10^{-3}$ & $\begin{array}{l}\text { Matias et al. } \\
2019 \text { [50] }\end{array}$ \\
\hline $\begin{array}{l}\mathrm{ZnO} / \text { ethylcellulose } \\
\text { composite on cork }\end{array}$ & $\mathrm{N} / \mathrm{A}$ & 5.0 & 3.6 & 1.5 & $2.00 \times 10^{-2}$ & $\mathrm{~N} / \mathrm{A}$ & $\begin{array}{l}\text { Figueira et al. } \\
2019 \text { [54] }\end{array}$ \\
\hline $\begin{array}{c}\mathrm{ZnO}-\text { cellulose } \\
\text { nanocomposite pellets }\end{array}$ & 60.00 & 5.0 & 8.0 & 10.0 & $3.09 \times 10^{-2}$ & $\mathrm{~N} / \mathrm{A}$ & $\begin{array}{l}\text { Sahoo et al. } \\
2020 \text { [93] }\end{array}$ \\
\hline $\begin{array}{c}\text { Commercial } \mathrm{ZnO} \\
\text { nanoparticles on paper }\end{array}$ & 10 & 5.0 & 10.0 & 10.0 & $\mathrm{~N} / \mathrm{A}$ & $\mathrm{N} / \mathrm{A}$ & $\begin{array}{l}\text { Dubourg et al. } \\
2021 \text { [94] }\end{array}$ \\
\hline
\end{tabular}


Figure $4 \mathrm{a}, \mathrm{b}$ depict the average photocurrent of the UV sensors under different applied voltages $(0.25,0.5,1$, and $2 \mathrm{~V})$ and the corresponding response current $(\Delta I)$ and responsivity. The bias voltage plays an important role in the electron-hole pair separation, recombination, and transportation processes and, therefore, it determines the overall photoresponse of the UV sensor [78]. The response current of the sensor increased almost linearly from $0.14 \pm 0.02$ to $1.34 \pm 0.15 \mathrm{~mA}$ when the applied voltage is varied from 0.25 to $2 \mathrm{~V}$, respectively. Typically, $\mathrm{ZnO}$ nanostructures present high recombination rates, low carrier mobilities, and high resistivities [77,78], which means that applied voltages above $1 \mathrm{~V}$ are usually needed to obtain a good response to UV light [78]. In this work, the sensors presented a very good responsivity even for low applied voltages $(<2 \mathrm{~V})$, reaching a value of $43.9 \pm 6.8 \mathrm{~mA} \mathrm{~W}^{-1}$ for $0.25 \mathrm{~V}$. The low-voltage operation of the fabricated screen-printed sensors is compatible with the emerging concept of IoT and demonstrates that these devices can be powered by portable power supplies, such as thin-film batteries or solar cells $[5,12,18,95]$. To the best of our knowledge, this is the first report showing low-powered and low-cost ZnO-based UV sensors on paper substrates with a response current in the $\mathrm{mA}$ range, as previously evidenced by Table 1 .

(a)

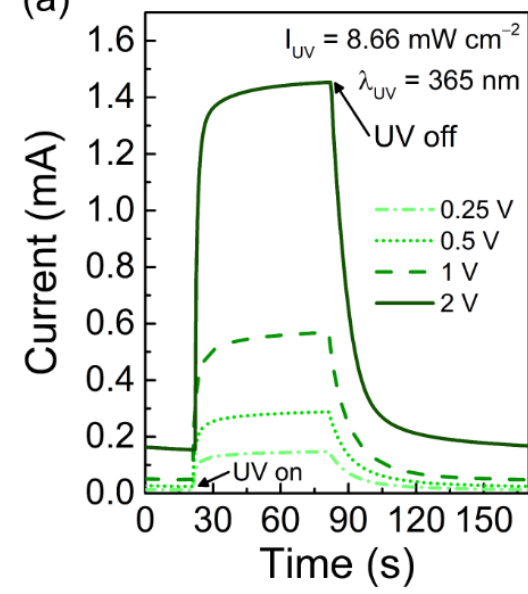

(b)

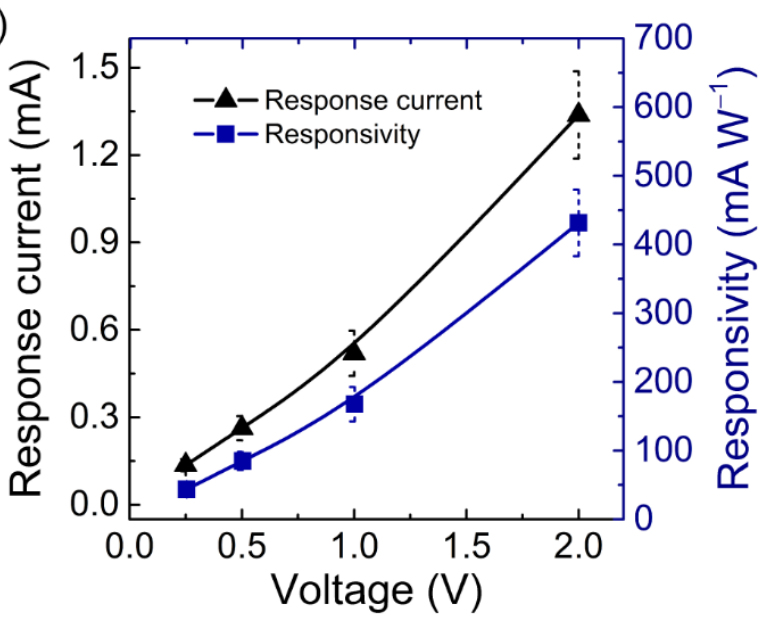

Figure 4. (a) Average photoresponse of the screen-printed CMC/ZnO UV sensor on office paper under different bias voltages for a UV light intensity of $8.66 \mathrm{~mW} \mathrm{~cm}^{-2}$. (b) Response current and respective responsivity for different applied voltages.

Figure $5 \mathrm{a}, \mathrm{b}$ show the average photocurrent for different UV light intensities and the calculated response current and responsivity for an applied voltage of $1 \mathrm{~V}$. In Figure $5 \mathrm{~b}$, the sensors' response current increases with UV light intensity, shifting from $0.17 \pm 0.02 \mathrm{~mA}$ for an intensity of $0.30 \mathrm{~mW} \mathrm{~cm}{ }^{-2}$ to $0.52 \pm 0.08 \mathrm{~mA}$ for an intensity of $8.66 \mathrm{~mW} \mathrm{~cm}^{-2}$. The UV light intensity is proportional to the number of photons irradiating the porous $\mathrm{ZnO}$ nanostructures for a certain UV wavelength. As such, when the UV intensity increases, the number of incident photons is higher and, consequently, more carriers are generated, and the response current is increased. On the other hand, the sensor's responsivity decreases with increasing UV irradiance. This is expected since the response current remains in the same order of magnitude $\left(10^{-1} \mathrm{~mA}\right)$ while the incident UV light power increases from 0.30 to $8.66 \mathrm{~mW} \mathrm{~cm}^{-2}$. As a result, the calculated responsivity $\left(\mathrm{mA} \mathrm{W}^{-1}\right)$ decreases with increasing UV light intensity. More importantly, the obtained results indicate that the produced UV sensors can respond to much weaker UV light, making these sensors suitable for the detection of low levels of UV light.

To evaluate the mechanical stability, a single $\mathrm{CMC} / \mathrm{ZnO}$ UV sensor was manually folded successive times and then flattened again prior to being subjected to a UV light intensity of $8.66 \mathrm{~mW} \mathrm{~cm} \mathrm{c}^{-2}$ under an applied voltage of $1 \mathrm{~V}$. The photoresponse was recorded after folding the sensor 100, 200, 500, and 1000 consecutive times. Figure 6a shows the normalized response current curves for the initial flat position and after being folded 
a different number of times. The response current reached by the sensor after $60 \mathrm{~s}$ of UV exposure decreased with the number of folds and its responsivity decreased by $1.5,9,20$, and $21 \%$ after the sensor has been folded 100, 200, 500, and 1000 times, respectively, as depicted in Figure 6b. As illustrated by the inset in Figure 6b, when the $\mathrm{ZnO}$ sensor was folded in half, a folding crease appeared across the sensor's layers and paper substrate, which was intensified as the number of folds increased. An SEM image of the crease folding area after the sensor had been folded 1000 times is shown in the left inset of Figure 6b. Here, some cracks are visible in the $\mathrm{CMC} / \mathrm{ZnO}$ layer deposited on paper. These cracks and their length increased in both the electrodes and $\mathrm{ZnO}$ photoactive layer with the number of folds, consequently leading to a decrease in the UV sensor's responsivity, since the path for the electrical carriers was broken in several places. Nonetheless, the produced $\mathrm{ZnO}$ sensors are capable of detecting UV light with very good responsivity even after being folded in half 1000 times, thus demonstrating their extremely high mechanical resistance. These results are of great significance since they validate the robustness of the fabricated $\mathrm{ZnO}$ UV sensors, therefore showing their potential to be used in wearable devices and smart packaging.
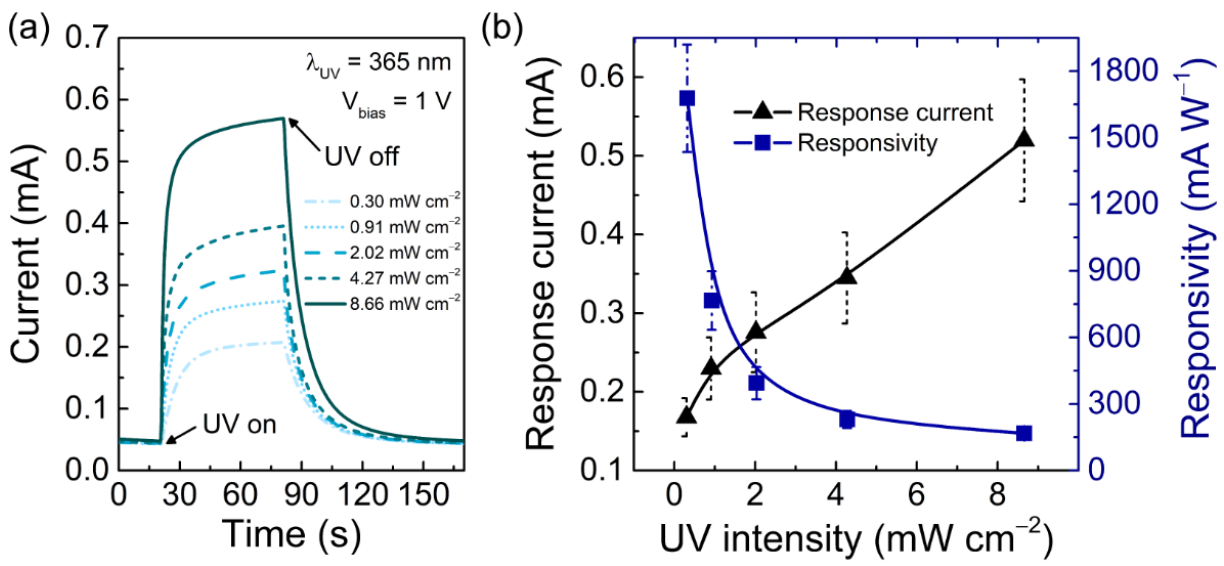

Figure 5. (a) Average photoresponse of the screen-printed CMC/ZnO UV sensor on office paper for different UV light intensities under a bias voltage of 1 V. (b) Response current and respective responsivity for different UV light intensities.

(a)

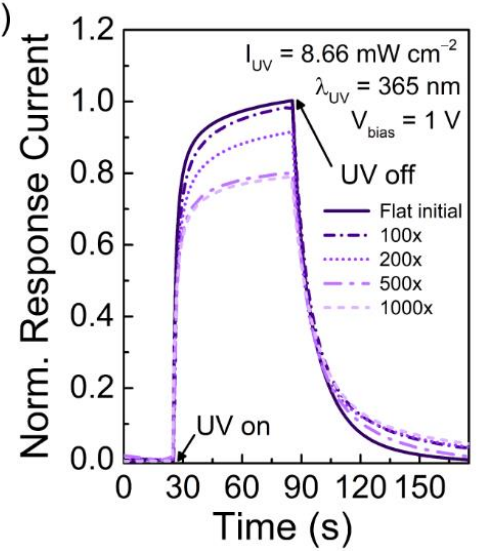

(b)

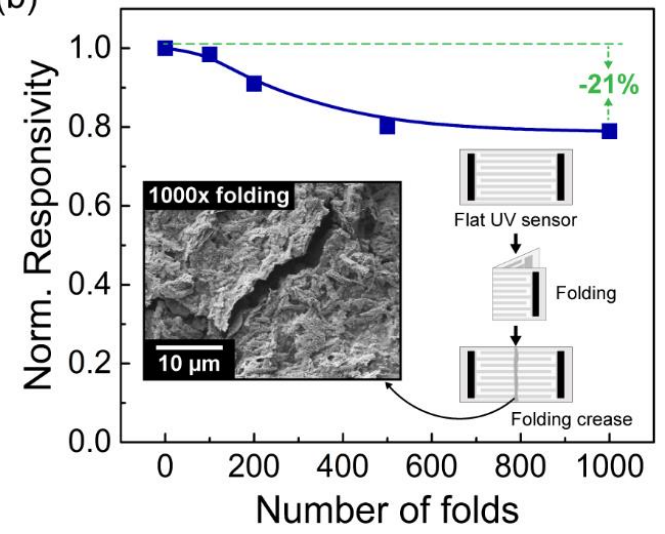

Figure 6. (a) Comparison of the normalized response current of a single screen-printed ZnO UV sensor in a flat position before and after being folded up to 1000 successive times. (b) Normalized responsivity of the UV sensor as a function of the number of folds. Inset of an illustration of the folding process and an SEM image showing the resulting cracks in the folding crease line of the sensor after being folded 1000 consecutive times. 


\section{Conclusions}

In summary, we demonstrated for the first time the use of porous $\mathrm{ZnO}$ nanostructures synthesized by microwave hydrothermal method to fabricate a water-based screenprintable ink where $\mathrm{CMC}$ was used as a binder. The $\mathrm{CMC} / \mathrm{ZnO}$ composite ink was successfully screen-printed on office paper to be used as the photoactive layer in UV sensors.

The fabricated $\mathrm{ZnO}$ UV sensors showed promising results for application in lowpower and flexible paper-based electronics. The tested sensors revealed a stable and good responsivity of $432 \pm 48 \mathrm{~mA} \mathrm{~W}^{-1}$ with a response current of $1.34 \pm 0.15 \mathrm{~mA}$ for an applied voltage of $2 \mathrm{~V}$, which are the highest values reported in the literature for UV sensors based either on $\mathrm{ZnO}$ nanostructures grown/deposited on paper or $\mathrm{ZnO} /$ cellulose composites. Furthermore, the $\mathrm{ZnO}$ sensors showed good responsivities even under low UV light intensity $\left(0.30 \mathrm{~mW} \mathrm{~cm}^{-2}\right)$ and ultra-low applied voltage $(0.25 \mathrm{~V})$. The produced UV sensors were also tested after being folded up to 1000 consecutive times with a decrease of only $21 \%$ in the final responsivity value, hence proving their potential for wearable technologies and smart packaging.

Author Contributions: Conceptualization, S.H.F. and I.C.; methodology, S.H.F., I.C., J.V.P. and J.P.N.; investigation, S.H.F. and I.C.; software, S.H.F. and J.P.N.; resources, J.P.N., L.P., E.F. and R.M.; data curation, S.H.F.; writing — original draft preparation, S.H.F.; writing — review and editing, I.C., J.V.P., J.P.N., L.P., E.F. and R.M.; supervision, L.P., E.F. and R.M.; funding acquisition, L.P., E.F. and R.M. All authors have read and agreed to the published version of the manuscript.

Funding: This work is funded by National Funds through FCT-Portuguese Foundation for Science and Technology, reference UIDB/50025/2020-2023 and FCT/MCTES. This work also received funding from the European Community's H2020 program under grant agreement No. 787410 (ERC-2018-AdG DIGISMART), No. 640598 (ERC-StG-2014, NEWFUN), and No. 952169 (SYNERGY, H2020-WIDESPREAD-2020-5, CSA). S.H.F. acknowledges the Portuguese Foundation for Science and Technology for the AdvaMTech PhD program scholarship PD/BD/114086/2015 and IDS-FunMatINNO project FPA2016/EIT/EIT RawMaterials Grant Agreement 17184. I.C. acknowledges the Portuguese Foundation for Science and Technology for the PhD scholarship SFRH/BD/126409/2016.

Institutional Review Board Statement: Not applicable.

Informed Consent Statement: Not applicable.

Data Availability Statement: The data presented in this study are available on request from the corresponding author.

Conflicts of Interest: The authors declare no conflict of interest.

\section{References}

1. Nandy, S.; Goswami, S.; Marques, A.; Gaspar, D.; Grey, P.; Cunha, I.; Nunes, D.; Pimentel, A.; Igreja, R.; Barquinha, P.; et al. Cellulose: A Contribution for the Zero e-Waste Challenge. Adv. Mater. Technol. 2021, 2000994. [CrossRef]

2. Zschieschang, U.; Klauk, H. Organic transistors on paper: A brief review. J. Mater. Chem. C 2019, 7, 5522-5533. [CrossRef]

3. Ha, D.; Fang, Z.; Zhitenev, N.B. Paper in Electronic and Optoelectronic Devices. Adv. Electron. Mater. 2018, 4, 1700593. [CrossRef]

4. Zhang, Y.; Zhang, L.; Cui, K.; Ge, S.; Cheng, X.; Yan, M.; Yu, J.; Liu, H. Flexible electronics based on micro/nanostructured paper. Adv. Mater. 2018, 30,1-39. [CrossRef]

5. Martins, R.; Gaspar, D.; Mendes, M.J.; Pereira, L.; Martins, J.; Bahubalindruni, P.; Barquinha, P.; Fortunato, E. Papertronics: Multigate paper transistor for multifunction applications. Appl. Mater. Today 2018, 12, 402-414. [CrossRef]

6. Russo, A.; Ahn, B.Y.; Adams, J.J.; Duoss, E.B.; Bernhard, J.T.; Lewis, J.A. Pen-on-Paper Flexible Electronics. Adv. Mater. 2011, 23, 3426-3430. [CrossRef]

7. Kurra, N.; Kulkarni, G.U. Pencil-on-paper: Electronic devices. Lab Chip 2013, 13, 2866. [CrossRef] [PubMed]

8. Lien, D.-H.; Kao, Z.-K.; Huang, T.-H.; Liao, Y.-C.; Lee, S.-C.; He, J.-H. All-Printed Paper Memory. ACS Nano 2014, 8, 7613-7619. [CrossRef] [PubMed]

9. Sia, S. Cutting edge: Thin, lightweight, foldable thermochromic displays on paper. Lab Chip 2009, 9, 2763. [CrossRef]

10. Tehrani, P.; Hennerdal, L.-O.; Dyer, A.L.; Reynolds, J.R.; Berggren, M. Improving the contrast of all-printed electrochromic polymer on paper displays. J. Mater. Chem. 2009, 19, 1799. [CrossRef]

11. Yoon, B.; Ham, D.-Y.; Yarimaga, O.; An, H.; Lee, C.W.; Kim, J.-M. Inkjet Printing of Conjugated Polymer Precursors on Paper Substrates for Colorimetric Sensing and Flexible Electrothermochromic Display. Adv. Mater. 2011, 23, 5492-5497. [CrossRef] [PubMed] 
12. Vicente, T.A.; Araújo, A.; Mendes, M.J.; Nunes, D.; Oliveira, M.J.; Sanchez-Sobrado, O.; Ferreira, M.P.; Águas, H.; Fortunato, E.; Martins, R. Multifunctional cellulose-paper for light harvesting and smart sensing applications. J. Mater. Chem. C 2018, 6, 3143-3181. [CrossRef]

13. Nuchtavorn, N.; Macka, M. A novel highly flexible, simple, rapid and low-cost fabrication tool for paper-based microfluidic devices ( $\mu$ PADs) using technical drawing pens and in-house formulated aqueous inks. Anal. Chim. Acta 2016, 919, 70-77. [CrossRef] [PubMed]

14. Hyun, W.J.; Secor, E.B.; Rojas, G.A.; Hersam, M.C.; Francis, L.F.; Frisbie, C.D. All-Printed, Foldable Organic Thin-Film Transistors on Glassine Paper. Adv. Mater. 2015, 27, 7058-7064. [CrossRef]

15. Thiemann, S.; Sachnov, S.J.; Pettersson, F.; Bollström, R.; Österbacka, R.; Wasserscheid, P.; Zaumseil, J. Cellulose-Based Ionogels for Paper Electronics. Adv. Funct. Mater. 2014, 24, 625-634. [CrossRef]

16. Ihalainen, P.; Määttänen, A.; Järnström, J.; Tobjörk, D.; Österbacka, R.; Peltonen, J. Influence of Surface Properties of Coated Papers on Printed Electronics. Ind. Eng. Chem. Res. 2012, 51, 6025-6036. [CrossRef]

17. Grau, G.; Kitsomboonloha, R.; Swisher, S.L.; Kang, H.; Subramanian, V. Printed Transistors on Paper: Towards Smart Consumer Product Packaging. Adv. Funct. Mater. 2014, 24, 5067-5074. [CrossRef]

18. Hong, K.; Kim, S.H.; Lee, K.H.; Frisbie, C.D. Printed, sub-2V ZnO Electrolyte Gated Transistors and Inverters on Plastic. Adv. Mater. 2013, 25, 3413-3418. [CrossRef]

19. Zheng, Y.; He, Z.; Gao, Y.; Liu, J. Direct Desktop Printed-Circuits-on-Paper Flexible Electronics. Sci. Rep. 2013, 3, 1786. [CrossRef]

20. Carvalho, J.T.; Dubceac, V.; Grey, P.; Cunha, I.; Fortunato, E.; Martins, R.; Clausner, A.; Zschech, E.; Pereira, L. Fully printed zinc oxide electrolyte-gated transistors on paper. Nanomaterials 2019, 9, 169. [CrossRef]

21. Grey, P.; Gaspar, D.; Cunha, I.; Barras, R.; Carvalho, J.T.; Ribas, J.R.; Fortunato, E.; Martins, R.; Pereira, L. Handwritten Oxide Electronics on Paper. Adv. Mater. Technol. 2017, 2, 170009. [CrossRef]

22. Fortunato, E.; Correia, N.; Barquinha, P.; Pereira, L.; Goncalves, G.; Martins, R. High-Performance Flexible Hybrid Field-Effect Transistors Based on Cellulose Fiber Paper. IEEE Electron Device Lett. 2008, 29, 988-990. [CrossRef]

23. Hu, G.; Kang, J.; Ng, L.W.T.; Zhu, X.; Howe, R.C.T.; Jones, C.G.; Hersam, M.C.; Hasan, T. Functional inks and printing of two-dimensional materials. Chem. Soc. Rev. 2018, 47, 3265-3300. [CrossRef]

24. Kamyshny, A.; Magdassi, S. Conductive Nanomaterials for Printed Electronics. Small 2014, 10, 3515-3535. [CrossRef]

25. Wu, W. Inorganic nanomaterials for printed electronics: A review. Nanoscale 2017, 9, 7342-7372. [CrossRef] [PubMed]

26. Capanema, N.S.V.; Mansur, A.A.P.; Carvalho, S.M.; Mansur, L.L.; Ramos, C.P.; Lage, A.P.; Mansur, H.S. Physicochemical properties and antimicrobial activity of biocompatible carboxymethylcellulose-silver nanoparticle hybrids for wound dressing and epidermal repair. J. Appl. Polym. Sci. 2018, 135, 45812. [CrossRef]

27. Solomon, M.M.; Gerengi, H.; Umoren, S.A. Carboxymethyl Cellulose/Silver Nanoparticles Composite: Synthesis, Characterization and Application as a Benign Corrosion Inhibitor for St37 Steel in 15\% H2SO4 Medium. ACS Appl. Mater. Interfaces 2017, 9 , 6376-6389. [CrossRef]

28. Kamal, T.; Ahmad, I.; Khan, S.B.; Ul-Islam, M.; Asiri, A.M. Microwave Assisted Synthesis and Carboxymethyl Cellulose Stabilized Copper Nanoparticles on Bacterial Cellulose Nanofibers Support for Pollutants Degradation. J. Polym. Environ. 2019, 27, 2867-2877. [CrossRef]

29. Bollström, R.; Tobjörk, D.; Dolietis, P.; Salminen, P.; Preston, J.; Österbacka, R.; Toivakka, M. Printability of functional inks on multilayer curtain coated paper. Chem. Eng. Process. Process Intensif. 2013, 68, 13-20. [CrossRef]

30. Tobjörk, D.; Österbacka, R. Paper electronics. Adv. Mater. 2011, 23, 1935-1961. [CrossRef]

31. Agate, S.; Joyce, M.; Lucia, L.; Pal, L. Cellulose and nanocellulose-based flexible-hybrid printed electronics and conductive composites-A review. Carbohydr. Polym. 2018, 198, 249-260. [CrossRef]

32. Inukai, K.; Takahashi, Y.; Ri, K.; Shin, W. Rheological analysis of ceramic pastes with ethyl cellulose for screen-printing. Ceram. Int. 2015, 41, 5959-5966. [CrossRef]

33. Faddoul, R.; Reverdy-Bruas, N.; Blayo, A. Formulation and screen printing of water based conductive flake silver pastes onto green ceramic tapes for electronic applications. Mater. Sci. Eng. B 2012, 177, 1053-1066. [CrossRef]

34. Lin, H.W.; Chang, C.P.; Hwu, W.H.; Ger, M.D. The rheological behaviors of screen-printing pastes. J. Mater. Process. Technol. 2008, 197, 284-291. [CrossRef]

35. Wang, Z.L. Zinc oxide nanostructures: Growth, properties and applications. J. Phys. Condens. Matter 2004, 16, R829-R858. [CrossRef]

36. Nunes, D.; Pimentel, A.; Goncalves, A.; Pereira, S.; Branquinho, R.; Barquinha, P.; Fortunato, E.; Martins, R. Metal oxide nanostructures for sensor applications. Semicond. Sci. Technol. 2019, 34, 043001. [CrossRef]

37. Arrabito, G.; Aleeva, Y.; Pezzilli, R.; Ferrara, V.; Medaglia, P.G.; Pignataro, B.; Prestopino, G. Printing ZnO Inks: From Principles to Devices. Crystals 2020, 10, 449. [CrossRef]

38. Agarwal, H.; Venkat Kumar, S.; Rajeshkumar, S. A review on green synthesis of zinc oxide nanoparticles-An eco-friendly approach. Resour. Technol. 2017, 3, 406-413. [CrossRef]

39. Naveed Ul Haq, A.; Nadhman, A.; Ullah, I.; Mustafa, G.; Yasinzai, M.; Khan, I. Synthesis Approaches of Zinc Oxide Nanoparticles: The Dilemma of Ecotoxicity. J. Nanomater. 2017, 2017, 8510342. [CrossRef]

40. Laurenti, M.; Cauda, V. Porous zinc oxide thin films: Synthesis approaches and applications. Coatings 2018, 8, 67. [CrossRef]

41. Mishra, Y.K.; Adelung, R. ZnO tetrapod materials for functional applications. Mater. Today 2018, 21, 631-651. [CrossRef] 
42. Kołodziejczak-Radzimska, A.; Jesionowski, T. Zinc Oxide-From Synthesis to Application: A Review. Materials 2014, 7, $2833-2881$. [CrossRef]

43. Fortunato, E.; Nunes, P.; Marques, A.; Costa, D.; Aguas, H.; Ferreira, I.; Godinho, M.H.; Almeida, P.L.; Borges, J.P.; Martins, R. Transparent, conductive ZnO:Al thin film deposited on polymer substrates by RF magnetron sputtering. Surf. Coatings Technol. 2002, 152, 247-251. [CrossRef]

44. Pimentel, A.; Gonçalves, A.; Marques, A.; Martins, R.; Fortunato, E. Role of the thickness on the electrical and optical performances of undoped polycrystalline zinc oxide films used as UV detectors. J. Non-Cryst. Solids 2006, 352, 1448-1452. [CrossRef]

45. Nunes, P.; Fortunato, E.; Lopes, A.; Martins, R. Influence of the deposition conditions on the gas sensitivity of zinc oxide thin films deposited by spray pyrolysis. Int. J. Inorg. Mater. 2001, 3, 1129-1131. [CrossRef]

46. Collins, M.J. Introduction to Microwave Chemistry. In Microwave Synthesis: Chemistry at the Speed of Light; Hayes, B.L., Ed.; CEM Publishing: Matthews, NC, USA, 2002; pp. 11-27. ISBN 0-9722229-01.

47. Mirzaei, A.; Neri, G. Microwave-assisted synthesis of metal oxide nanostructures for gas sensing application: A review. Sens. Actuators B Chem. 2016, 237, 749-775. [CrossRef]

48. Ferreira, S.H.; Deuermeier, J.; Sequeira, S.; Nunes, D.; Gonçalves, A.M.F.; Martins, R.; Monteiro, R.C.C.; Fortunato, E. Industrial waste residue converted into value-added ZnO for optoelectronic applications. ACS Appl. Electron. Mater. 2020, 2, 1960-1969. [CrossRef]

49. Pimentel, A.; Samouco, A.; Nunes, D.; Araújo, A.; Martins, R.; Fortunato, E. Ultra-fast microwave synthesis of ZnO nanorods on cellulose substrates for UV sensor applications. Materials 2017, 10, 1308. [CrossRef]

50. Matias, M.L.; Nunes, D.; Pimentel, A.; Ferreira, S.H.; Borda d'Agua, R.; Duarte, M.P.; Fortunato, E.; Martins, R. Paper-Based Nanoplatforms for Multifunctional Applications. J. Nanomater. 2019, 2019, 6501923. [CrossRef]

51. Filip, A.; Musat, V.; Tigau, N.; Polosan, S.; Pimentel, A.; Ferreira, S.; Gomes, D.; Calmeiro, T.; Martins, R.; Fortunato, E. ZnO nanostructures grown on ITO coated glass substrate by hybrid microwave-assisted hydrothermal method. Optik 2020, $208,164372$. [CrossRef]

52. Wojnarowicz, J.; Chudoba, T.; Lojkowski, W. A Review of Microwave Synthesis of Zinc Oxide Nanomaterials: Reactants, Process Parameters and Morphologies. Nanomaterials 2020, 10, 1086. [CrossRef]

53. Claro, P.I.C.; Marques, A.C.; Cunha, I.; Martins, R.F.P.; Pereira, L.M.N.; Marconcini, J.M.; Mattoso, L.H.C.; Fortunato, E. Tuning the Electrical Properties of Cellulose Nanocrystals through Laser-Induced Graphitization for UV Photodetectors. ACS Appl. Nano Mater. 2021. [CrossRef]

54. Figueira, J.; Gaspar, C.; Carvalho, J.T.; Loureiro, J.; Fortunato, E.; Martins, R.; Pereira, L. Sustainable Fully Printed UV Sensors on Cork Using Zinc Oxide/Ethylcellulose Inks. Micromachines 2019, 10, 601. [CrossRef]

55. Zargar, R.A.; Chackrabarti, S.; Joseph, S.; Khan, M.S.; Husain, R.; Hafiz, A.K. Synthesis and characterization of screen printed ZnO films for solar cell applications. Optik 2015, 126, 4171-4174. [CrossRef]

56. Fekete, M.; Riedel, W.; Patti, A.F.; Spiccia, L. Photoelectrochemical water oxidation by screen printed ZnO nanoparticle films: Effect of $\mathrm{pH}$ on catalytic activity and stability. Nanoscale 2014, 6, 7585-7593. [CrossRef]

57. Manjunath, G.; Pujari, S.; Patil, D.R.; Mandal, S. A scalable screen-printed high performance ZnO-UV and Gas Sensor: Effect of solution combustion. Mater. Sci. Semicond. Process. 2020, 107, 104828. [CrossRef]

58. Wen, M.J.; Subramani, S.; Devarajan, M.; Sulaiman, F. Effect of ethyl cellulose on thermal resistivity of thixotropic ZnO nanoparticle paste for thermal interface material in light emitting diode application. Mater. Sci. Semicond. Process. 2017, 58, 61-67. [CrossRef]

59. Jang, J.S.; Lee, S.E.; Choi, S.J.; Koo, W.T.; Kim, D.H.; Shin, H.; Park, H.J.; Kim, I.D. Heterogeneous, Porous 2D Oxide Sheets via Rapid Galvanic Replacement: Toward Superior HCHO Sensing Application. Adv. Funct. Mater. 2019, 29, 1-10. [CrossRef]

60. Xie, X.; Wang, X.; Tian, J.; Song, X.; Wei, N.; Cui, H. Growth of porous ZnO single crystal hierarchical architectures with ultrahigh sensing performances to ethanol and acetone gases. Ceram. Int. 2017, 43, 1121-1128. [CrossRef]

61. Li, B.; Wang, Y. Hierarchically assembled porous ZnO microstructures and applications in a gas sensor. Superlattices Microstruct. 2011, 49, 433-440. [CrossRef]

62. Chen, M.; Wang, Z.; Han, D.; Gu, F.; Guo, G. Porous ZnO polygonal nanoflakes: Synthesis, use in high-sensitivity NO 2 gas sensor, and proposed mechanism of gas sensing. J. Phys. Chem. C 2011, 115, 12763-12773. [CrossRef]

63. Zhang, L.; Zhao, J.; Lu, H.; Li, L.; Zheng, J.; Li, H.; Zhu, Z. Facile synthesis and ultrahigh ethanol response of hierarchically porous ZnO nanosheets. Sens. Actuators B Chem. 2012, 161, 209-215. [CrossRef]

64. Chang, J.; Ahmad, M.Z.; Wlodarski, W.; Waclawik, E.R. Self-assembled 3D ZnO porous structures with exposed reactive \{0001\} facets and their enhanced gas sensitivity. Sensors 2013, 13, 8445-8460. [CrossRef]

65. Qiu, Y.; Chen, W.; Yang, S. Facile hydrothermal preparation of hierarchically assembled, porous single-crystalline ZnO nanoplates and their application in dye-sensitized solar cells. J. Mater. Chem. 2010, 20, 1001-1006. [CrossRef]

66. Teng, Y.; Mo, M.; Li, Y.; Xue, J.; Zhao, H. Amorphous carbon-coated ZnO porous nanosheets: Facile fabrication and application in lithium- and sodium-ion batteries. J. Alloys Compd. 2018, 744, 712-720. [CrossRef]

67. Ferreira, S.H.; Morais, M.; Nunes, D.; Oliveira, M.J.; Rovisco, A.; Pimentel, A.; Águas, H.; Fortunato, E.; Martins, R. High UV and Sunlight Photocatalytic Performance of Porous ZnO Nanostructures Synthesized by a Facile and Fast Microwave Hydrothermal Method. Materials 2021, 14, 2385. [CrossRef] [PubMed] 
68. Liu, S.; Li, C.; Yu, J.; Xiang, Q. Improved visible-light photocatalytic activity of porous carbon self-doped ZnO nanosheetassembled flowers. CrystEngComm 2011, 13, 2533-2541. [CrossRef]

69. Liu, D.; Lv, Y.; Zhang, M.; Liu, Y.; Zhu, Y.; Zong, R.; Zhu, Y. Defect-related photoluminescence and photocatalytic properties of porous $\mathrm{ZnO}$ nanosheets. J. Mater. Chem. A 2014, 2, 15377-15388. [CrossRef]

70. Yang, H.; Ni, S.Q.; Jiang, X.; Jiang, W.; Zhan, J. In situ fabrication of single-crystalline porous ZnO nanoplates on zinc foil to support silver nanoparticles as a stable SERS substrate. CrystEngComm 2012, 14, 6023-6028. [CrossRef]

71. Bitenc, M.; Marinšek, M.; Crnjak Orel, Z. Preparation and characterization of zinc hydroxide carbonate and porous zinc oxide particles. J. Eur. Ceram. Soc. 2008, 28, 2915-2921. [CrossRef]

72. Gu, F.; You, D.; Wang, Z.; Han, D.; Guo, G. Improvement of gas-sensing property by defect engineering in microwave-assisted synthesized 3D ZnO nanostructures. Sens. Actuators B Chem. 2014, 204, 342-350. [CrossRef]

73. Zhang, Y.; Liu, C.; Gong, F.; Jiu, B.; Li, F. Large scale synthesis of hexagonal simonkolleit nanosheets for ZnO gas sensors with enhanced performances. Mater. Lett. 2017, 186, 7-11. [CrossRef]

74. Ferreira, S.H.; Rovisco, A.; dos Santos, A.; Águas, H.; Igreja, R.; Barquinha, P.; Fortunato, E.; Martins, R. Porous ZnO Nanostructures Synthesized by Microwave Hydrothermal Method for Energy Harvesting Applications. In Nanopores; Ameen, S., Ed.; IntechOpen: London, UK, 2021; ISBN 978-1-83880-210-3.

75. Tran, V.T.; Wei, Y.; Yang, H.; Zhan, Z.; Du, H. All-inkjet-printed flexible ZnO micro photodetector for a wearable UV monitoring device. Nanotechnology 2017, 28, 095204. [CrossRef] [PubMed]

76. Xu, Q.; Cheng, L.; Meng, L.; Wang, Z.; Bai, S.; Tian, X.; Jia, X.; Qin, Y. Flexible Self-Powered ZnO Film UV Sensor with a High Response. ACS Appl. Mater. Interfaces 2019, 11, 26127-26133. [CrossRef] [PubMed]

77. Garlapati, S.K.; Divya, M.; Breitung, B.; Kruk, R.; Hahn, H.; Dasgupta, S. Printed Electronics Based on Inorganic Semiconductors: From Processes and Materials to Devices. Adv. Mater. 2018, 30, 1-55. [CrossRef]

78. Deka Boruah, B. Zinc oxide ultraviolet photodetectors: Rapid progress from conventional to self-powered photodetectors. Nanoscale Adv. 2019, 1, 2059-2085. [CrossRef]

79. Li, Y.; Della Valle, F.; Simonnet, M.; Yamada, I.; Delaunay, J.J. High-performance UV detector made of ultra-long ZnO bridging nanowires. Nanotechnology 2009, 20, 045501. [CrossRef] [PubMed]

80. Sysoev, V.V.; Goschnick, J.; Schneider, T.; Strelcov, E.; Kolmakov, A. A gradient microarray electronic nose based on percolating SnO 2 nanowire sensing elements. Nano Lett. 2007, 7, 3182-3188. [CrossRef] [PubMed]

81. Humayun, Q.; Kashif, M.; Hashim, U.; Qurashi, A. Selective growth of ZnO nanorods on microgap electrodes and their applications in UV sensors. Nanoscale Res. Lett. 2014, 9, 29. [CrossRef] [PubMed]

82. Lee, D.; Seol, M.-L.; Motilal, G.; Kim, B.; Moon, D.-I.; Han, J.-W.; Meyyappan, M. All 3D-Printed Flexible ZnO UV Photodetector on an Ultraflat Substrate. ACS Sens. 2020, 5, 1028-1032. [CrossRef] [PubMed]

83. Asib, N.A.M.; Husairi, F.S.; Eswar, K.A.; Afaah, A.N.; Mamat, M.H.; Rusop, M.; Khusaimi, Z. Developing high-sensitivity UV sensors based on $\mathrm{ZnO}$ nanorods grown on $\mathrm{TiO} 2$ seed layer films using solution immersion method. Sens. Actuators A Phys. 2020, 302, 111827. [CrossRef]

84. Gedamu, D.; Paulowicz, I.; Kaps, S.; Lupan, O.; Wille, S.; Haidarschin, G.; Mishra, Y.K.; Adelung, R. Rapid fabrication technique for interpenetrated $\mathrm{ZnO}$ nanotetrapod networks for fast UV sensors. Adv. Mater. 2014, 26, 1541-1550. [CrossRef]

85. Bai, S.; Wu, W.; Qin, Y.; Cui, N.; Bayerl, D.J.; Wang, X. High-performance integrated ZnO nanowire UV sensors on rigid and flexible substrates. Adv. Funct. Mater. 2011, 21, 4464-4469. [CrossRef]

86. Manekkathodi, A.; Lu, M.Y.; Wang, C.W.; Chen, L.J. Direct growth of aligned zinc oxide nanorods on paper substrates for low-cost flexible electronics. Adv. Mater. 2010, 22, 4059-4063. [CrossRef] [PubMed]

87. Gimenez, A.J.; Yáñez-Limón, J.M.; Seminario, J.M. ZnO-paper based photoconductive UV sensor. J. Phys. Chem. C 2011, 115, 282-287. [CrossRef]

88. Ul Hasan, K.; Nur, O.; Willander, M. Screen printed ZnO ultraviolet photoconductive sensor on pencil drawn circuitry over paper. Appl. Phys. Lett. 2012, 100, 21104. [CrossRef]

89. Kiasari, N.M.; Soltanian, S.; Gholamkhass, B.; Servati, P. Sketching functional, ubiquitous ZnO nano-sensors on paper. RSC Adv. 2014, 4, 19663-19667. [CrossRef]

90. Sahoo, K.; Biswas, A.; Nayak, J. Effect of synthesis temperature on the UV sensing properties of ZnO-cellulose nanocomposite powder. Sens. Actuators A Phys. 2017, 267, 99-105. [CrossRef]

91. Veerla, R.S.; Sahatiya, P.; Badhulika, S. Fabrication of a flexible UV photodetector and disposable photoresponsive uric acid sensor by direct writing of $\mathrm{ZnO}$ pencil on paper. J. Mater. Chem. C 2017, 5, 10231-10240. [CrossRef]

92. Mun, S.; Kim, H.C.; Ko, H.U.; Zhai, L.; Kim, J.W.; Kim, J. Flexible cellulose and ZnO hybrid nanocomposite and its UV sensing characteristics. Sci. Technol. Adv. Mater. 2017, 18, 437-446. [CrossRef] [PubMed]

93. Sahoo, K.; Mohanty, B.; Biswas, A.; Nayak, J. Role of hexamethylenetetramine in ZnO-cellulose nanocomposite enabled UV and humidity sensor. Mater. Sci. Semicond. Process. 2020, 105, 104699. [CrossRef] 
94. Dubourg, G.; Radovic, M.; Vasic, B. Laser-tunable printed zno nanoparticles for paper-based uv sensors with reduced humidity interference. Nanomaterials 2021, 11, 80. [CrossRef] [PubMed]

95. Adila, A.S.; Husam, A.; Husi, G. Towards the self-powered Internet of Things (IoT) by energy harvesting: Trends and technologies for green IoT. In Proceedings of the 2018 2nd International Symposium on Small-Scale Intelligent Manufacturing Systems (SIMS), Cavan, Ireland, 16-18 April 2018; IEEE: Piscataway, NJ, USA, 2018; pp. 1-5, ISBN 978-1-5386-4437-9. 